\title{
Synapse-Associated Protein 102/dlgh3 Couples the NMDA Receptor to Specific Plasticity Pathways and Learning Strategies
}

\author{
Peter C. Cuthbert, ${ }^{1,2 *}$ Lianne E. Stanford, ${ }^{1 \star}$ Marcelo P. Coba, ${ }^{1}$ James A. Ainge, ${ }^{2}$ Ann E. Fink, ${ }^{3}$ Patricio Opazo, ${ }^{3}$ \\ Jary Y. Delgado, ${ }^{3}$ Noboru H. Komiyama, ${ }^{1,2}$ Thomas J. 0'Dell, ${ }^{3}$ and Seth G. N. Grant ${ }^{1,2}$ \\ ${ }^{1}$ Wellcome Trust Sanger Institute, Cambridge CB10 1SA, United Kingdom, ${ }^{2}$ Centre for Neuroscience Research, Edinburgh University, Edinburgh EH9 $1 \mathrm{QH}$, \\ United Kingdom, and ${ }^{3}$ University of California, Los Angeles Brain Research Institute, Los Angeles, California 90095
}

\begin{abstract}
Understanding the mechanisms whereby information encoded within patterns of action potentials is deciphered by neurons is central to cognitive psychology. The multiprotein complexes formed by NMDA receptors linked to synaptic membrane-associated guanylate kinase (MAGUK) proteins including synapse-associated protein 102 (SAP102) and other associated proteins are instrumental in these processes. Although humans with mutations in SAP102 show mental retardation, the physiological and biochemical mechanisms involved are unknown. Using SAP102 knock-out mice, we found specific impairments in synaptic plasticity induced by selective frequencies of stimulation that also required extracellular signal-regulated kinase signaling. This was paralleled by inflexibility and impairment in spatial learning. Improvement in spatial learning performance occurred with extra training despite continued use of a suboptimal search strategy, and, in a separate nonspatial task, the mutants again deployed a different strategy. Double-mutant analysis of postsynaptic density-95 and SAP102 mutants indicate overlapping and specific functions of the two MAGUKs. These in vivo data support the model that specific MAGUK proteins couple the NMDA receptor to distinct downstream signaling pathways. This provides a mechanism for discriminating patterns of synaptic activity that lead to long-lasting changes in synaptic strength as well as distinct aspects of cognition in the mammalian nervous system.
\end{abstract}

Key words: SAP102; spike-timing; MAGUK; ERK; plasticity; learning

\section{Introduction}

Investigation into the molecular mechanisms allowing patterns of neuronal activity to induce plasticity in mammalian neurons and behavior has focused on the role of the NMDA subtype of glutamate receptor receptors and a multitude of signaling proteins. Comprising NR1 and NR2 subunits that form a Ca ${ }^{2+}$ channel, the NMDA receptor is physically linked to cytoplasmic proteins by C-terminal domains of its subunits forming multiprotein complexes, known as the NMDA receptor complex (NRC). Membrane-associated guanylate kinase (MAGUK) proteins, including synapse-associated protein 102 (SAP102), postsynaptic density-95 (PSD-95), and PSD-93, are proximal components of the NRC and directly bind to NR2 subunits (Kornau et al., 1995; Kim et al., 1996; Lau et al., 1996; Muller et al., 1996) and dozens of different enzymes and scaffold and cytoskeletal proteins (E. Kim et al., 1997; Makino et al., 1997; Takeuchi et al., 1997; J. H. Kim et al., 1998; Firestein et al., 1999; Masuko et al., 1999; Chen et al., 2000; Husi et al., 2000; Penzes et al., 2001; Komiyama et al., 2002;

\footnotetext{
Received 0ct. 13, 2006; revised Dec. 18, 2006; accepted Jan. 9, 2007

*P.C.C. and L.E.S. contributed equally to this work.

Correspondence should be addressed to Dr. Seth G. N. Grant, Wellcome Trust Sanger Institute, Cambridge CB10

1SA, UK. E-mail: sg3@sanger.ac.uk.

DOI:10.1523/JNEUROSCI.4457-06.2007

Copyright $\odot 2007$ Society for Neuroscience $\quad$ 0270-6474/07/272673-10\$15.00/0
}

Sans et al., 2003; Seabold et al., 2003; Montgomery et al., 2004; Grant et al., 2005).

A detailed understanding of the biology of MAGUK proteins in vivo, and in particular their differential and specific functions, is lacking. Recently, the first example of a human mutation in a MAGUK protein was reported. Loss-of-function mutations in the SAP102 gene (dlg3/dlgh3/NE-dlg) cause nonsyndromic X-linked mental retardation (Tarpey et al., 2004). Previous mouse genetic studies show that loss-of-function of PSD-95 results in impairment in forms of plasticity in the hippocampus (spatial learning deficits) (Migaud et al., 1998), spinal cord (nociceptive pain) (Garry et al., 2003), cortex (visual plasticity) (Fagiolini et al., 2003), and striatum (cocaine sensitization) (Yao et al., 2004).

An important dimension to the induction of plasticity is the ability of the synapse to detect and discriminate different patterns of neuronal activity. Long-term potentiation (LTP) has been used as a model for examining the effects of different stimulation paradigms, such as frequencies and durations of trains, or the relative timing of presynaptic and postsynaptic activity (spiketiming plasticity). Although the NMDA receptor can transduce a $\mathrm{Ca}^{2+}$ signal from as little as a single quanta of glutamate (Emptage et al., 1999), the activation of the NMDA receptor by different stimulation paradigms, all of which may lead to LTP, does not use a single pathway or set of postsynaptic proteins. For 
example, inhibition of extracellular signal-regulated kinase (ERK)/mitogen-activated protein kinase (MAPK) does not block LTP induced by $100 \mathrm{~Hz}$ stimulation, although it blocks $5 \mathrm{~Hz}$ induced LTP (Winder et al., 1999). In contrast to this trainspecific dependency in the ERK pathway, PSD-95 mutant mice show impaired induction of LTP, with trains ranging from 1 to $100 \mathrm{~Hz}$ (Migaud et al., 1998; Komiyama et al., 2002). Therefore, the NMDA receptor must have some way of linking to different sets of downstream proteins, which can each regulate LTP. The simplest explanation would be that the NMDA receptor subunits would couple to these distinct pathways using specific adaptor proteins, such as the MAGUKs. A prediction of this model would be that mutation of specific MAGUKs would result in impairments of specific forms of LTP.

Here we report the first characterization of SAP 102 knock-out mice. We found that SAP102 was required for the induction of LTP and spike-timing-dependent plasticity but with a restricted range of stimulation conditions. This restricted range corresponded to that of ERK pathway function, which was altered in the mutant mice. The SAP102 mutant mice showed cognitive deficits with a specific spatial learning deficit that was overcome by additional training. We also document a role for SAP102 in a higher cognitive function, that of strategy utilization for problem solving. Thus, SAP102 confers selective signal transduction to the NMDA receptor in vivo and specific cognitive functions.

\section{Materials and Methods}

\section{Gene targeting}

HM1 mouse embryonic stem (ES) cells were targeted with a vector containing 3.6 and $4.5 \mathrm{~kb}$ fragments of flanking genomic DNA, replacing 4.9 $\mathrm{kb}$ of SAP102 genomic DNA (X95,371,637 to X95,376,592; Ensembl Build 32) with the positive selectable marker PGKneopA (neomycin). The negative selectable marker MC1DTA was placed adjacent to the targeting construct. For Southern blot analysis, $15 \mathrm{mg}$ of DNA from ES cells or tail or ear tips was digested with DraI or NheI and probed with a $5^{\prime}$ probe $\left(\mathrm{X} 95,367,143\right.$ to X95,367,879) or a $3^{\prime}$ probe (X95,381,200 to $\mathrm{X} 95,382,085)$ outside the homology region, respectively. PCR genotyping consisted of two independent reactions. A $535 \mathrm{bp}$ product was selectively amplified from the wild-type (wt) allele using a forward primer $\mathrm{P} 1$ (GGTCTCTGATGAAGCAGTGATTTTT) upstream of the selection cassette integration site and a reverse primer P2 (TGATGACCCATAGACAGTAGGATCA) in the wt sequence deleted by the targeted mutation. From the targeted allele, a 215 bp product was amplified using $\mathrm{P} 1$ with a reverse primer P3 (CTAAAGCGCATGCTCCAGAC) from within the selection cassette. Amplification was 33 cycles of 30 s at $94^{\circ} \mathrm{C}, 30$ s at $56^{\circ} \mathrm{C}$, and $60 \mathrm{~s}$ at $72^{\circ} \mathrm{C}$. Mice used for experimental analyses were $4-$ to 7 -month-old males from the second generation of intercrosses between the chimeras and MF1 strain mice.

\section{Biochemistry}

Standard procedures were used for protein extraction, SDS-PAGE, and Western blotting (Komiyama et al., 2002). Primary antibodies are listed in supplemental Table 1 (available at www.jneurosci.org as supplemental material). ELISAs were performed according to the instructions of the manufacturer to determine endogenous levels of ERK1/2 (total ERK1/2; Biosource, Camarillo, CA) and phospho-ERK1/2 T202/Y204 (Pathscan; Cell Signaling Technology, Beverly, MA). For the phosphorylation screen, dissected hippocampi were homogenized in $20 \mathrm{~mm} \mathrm{3-}(\mathrm{N}$ morpholino)-propanesulfonic acid, pH 7.4, 2 mм EDTA, 5 mм EGTA, $0.5 \%$ Triton X-100, $30 \mathrm{~mm} \mathrm{NaF}, 40 \mathrm{~mm} \beta$-glycerophosphate, $20 \mathrm{~mm}$ sodium pyrophosphate, $1 \mathrm{~mm}$ sodium orthovanadate, $1 \mathrm{~mm}$ PMSF, $3 \mathrm{~mm}$ benzamidine, $5 \mu \mathrm{M}$ pepstatin, and $10 \mu \mathrm{M}$ leupeptin and subjected to a phospho-site screen (KPSS-1.3) by Kinexus Bioinformatics Corporation (Vancouver, British Columbia, Canada). Neuroanatomical protocols are described in the supplemental Materials and Methods (available at www.jneurosci.org as supplemental material).

\section{Behavioral testing}

A behavioral test battery, including a rotorod, forelimb grip-strength assessment, open field, and elevated plus maze was completed to look for gross behavioral abnormalities in the mice. Full details for these protocols are found in the supplemental Materials and Methods (available at www.jneurosci.org as supplemental material). A water maze test modified to include extra probe trials was completed on a second cohort of animals derived from the same parents as detailed below.

Water maze: apparatus. Briefly, an open-field water maze was used (2 m diameter, opaque water, $25 \pm 1^{\circ} \mathrm{C}$ ) with Actimetrics (Wilmette, IL) automated swim path analysis software. The escape platform was $30 \mathrm{~cm}$ in diameter and was made visible by lowering the level of the water in the pool and adding a flag to the center of the platform. A black curtain could be drawn around the maze when required to eliminate the visible cues from within the room.

Protocol. The protocol was adapted from published methods (Migaud et al., 1998; Komiyama et al., 2002). Mice were trained in a 2-m-diameter pool to first find a visible platform (visible, four trials for $3 \mathrm{~d}$ ), then to find a submerged platform (hidden, four trials for $5 \mathrm{~d}$ ), and finally to find a submerged platform in the opposite quadrant (reversal, four trials for $5 \mathrm{~d}$ ). Probe tests were completed $10 \mathrm{~min}$ after the hidden platform training (H1) and 18-24 h after H1 (H2). Supplementary probe tests were also completed 10 min after each of the first four reversal training days (R1$\mathrm{R} 4$ ), along with the more traditional ones at $10 \mathrm{~min}$ after the last trial on the last day of training (R5) and at 18-24 h after training (R6). We then tested long-term memory retention at 1,2 , and 8 weeks after reversal training (R7, R8, and R9). The maximum duration for training trials was $90 \mathrm{~s}$, and, during each, latency to reach the platform, distance swum, and swimming speed were calculated. All probe trials were $60 \mathrm{~s}$, and data on the time spent in each quadrant and the number of platform location crossings were collected.

Data analysis. Two-way (genotype $\times$ day) mixed ANOVAs were completed for latency, distance, and swim speed. For the probe trials, twoway (genotype $\times$ quadrant) mixed ANOVAs were completed. Onegroup $t$ tests were also completed, to assess whether each of the mean "training quadrant" times for each genotype were above chance (15 s).

Each swim path trace was also printed out and scored by three observers blind to the genotype or day of the trace. The scoring was based on seven qualitative patterns published previously (Graziano et al., 2003), so that swim strategy could be assessed. To do this, the scores from the three observers were concatenated, and paths were "scored" if at least two observers agreed with the swim path style. The strategies were then entered into a spreadsheet so that percentages of the seven categories could be calculated. These were then statistically assessed with Cochran's $Q$ and then $\chi^{2}$ nonparametric tests.

\section{Electrophysiology}

Electrophysiological experiments were performed as described previously (Komiyama et al., 2002). Slices, $400 \mu \mathrm{m}$ thick, of mouse hippocampus were maintained at $30^{\circ} \mathrm{C}$ in an interface-type recording chamber perfused with a murine artificial CSF (ACSF) containing the following (in mM): $124 \mathrm{NaCl}, 4.4 \mathrm{KCl}, 25 \mathrm{Na}_{2} \mathrm{HCO}_{3}, 1 \mathrm{NaH}_{2} \mathrm{PO}_{4}, 1.2 \mathrm{MgSO}_{4}, 2$ $\mathrm{CaCl}_{2}$, and 10 glucose. All experiments were performed using slices obtained from 4- to 7-month-old SAP102 ${ }^{-/ y}$ and their wt littermates. In extracellular recordings, field EPSPs (fEPSPs) were elicited once every $50 \mathrm{~s}(0.01 \mathrm{~Hz}, 0.01-0.02 \mathrm{~ms}$ duration pulses using tungsten wire bipolar stimulation electrodes placed in stratum radiatum of the CA1 region). The evoked fEPSPs were recorded using low-resistance glass microelectrodes (5-10 M $\Omega$, filled with ACSF), also placed in CAl stratum radiatum. Whole-cell current-clamp recordings of EPSPs were performed using recording electrodes filled with a solution containing the following (in mM): $135 \mathrm{~K}$-gluconate, $20 \mathrm{KCl}, 2 \mathrm{MgCl} 2,10 \mathrm{HEPES}, 2 \mathrm{ATP}$, and 0.3 GTP, pH 7.2 (electrode resistance, $2-5 \mathrm{M} \Omega$ ). In whole-cell voltage-clamp recordings of EPSCs, the recording electrode solution contained the following (in $\mathrm{mm}$ ): 122.5 Cs-gluconate, $17.5 \mathrm{CsCl}, \quad 10$ tetraethylammonium-Cl, 0.2 EGTA, 10 HEPES, 2 Mg-ATP, and 0.3 GTP, $\mathrm{pH}$ 7.2. In all whole-cell recordings, the hippocampal CA3 region was removed and slices were bathed in a modified ACSF containing $100 \mu \mathrm{M}$ picrotoxin, $4 \mathrm{mM} \mathrm{CaCl}_{2}$, and $2.4 \mathrm{~mm} \mathrm{MgSO}_{4}$. 
a
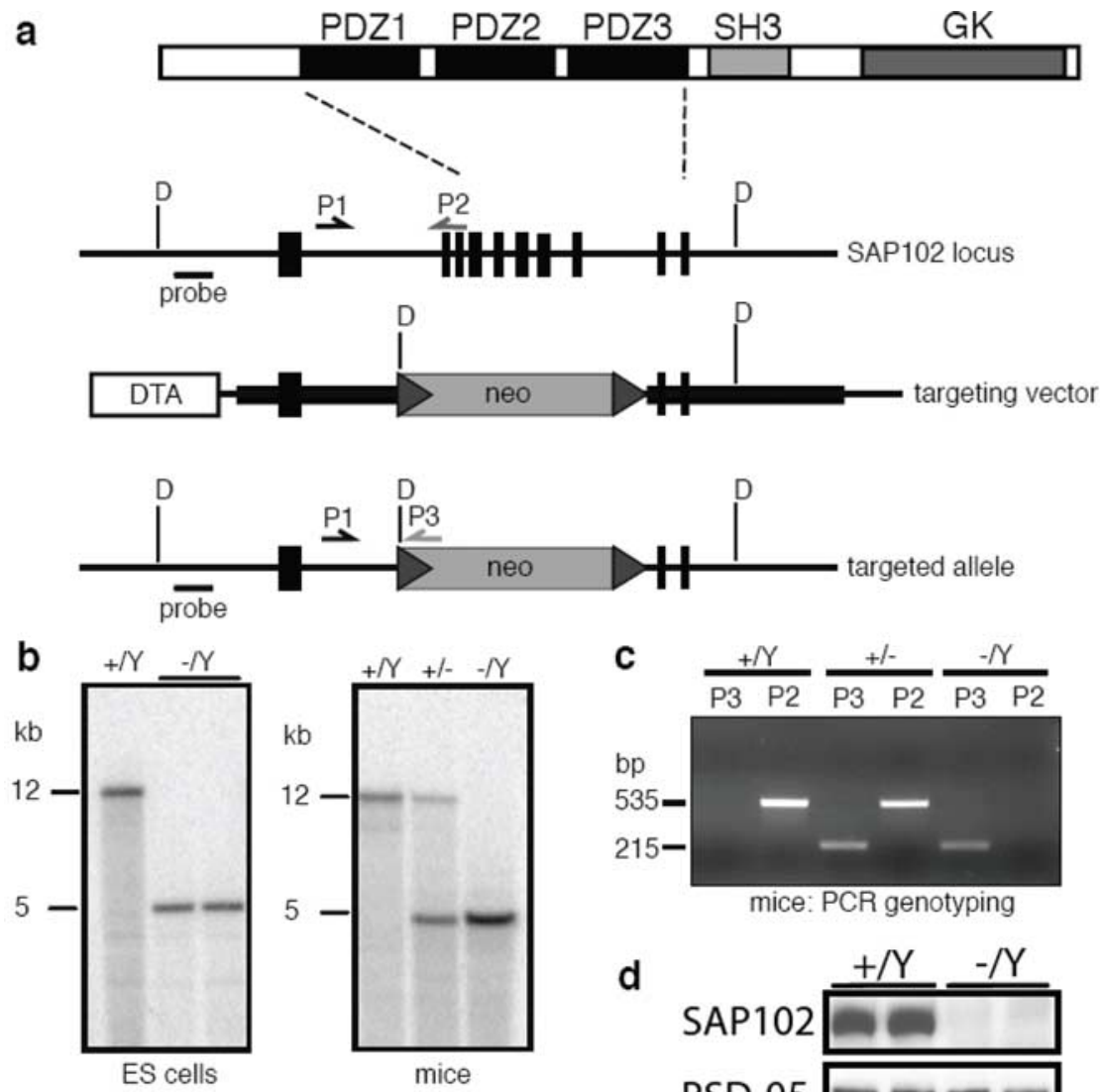

C
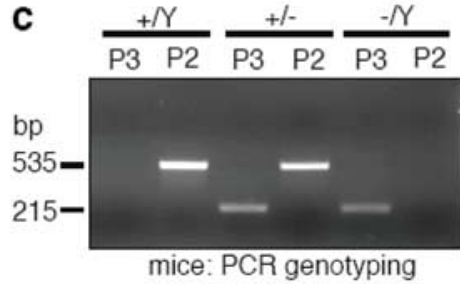

d

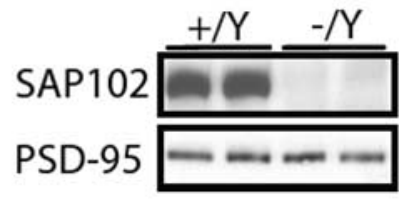

e

SAP102
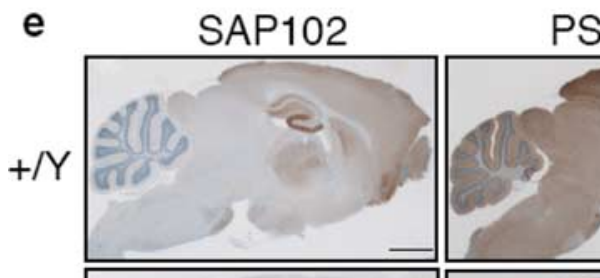

PSD-95
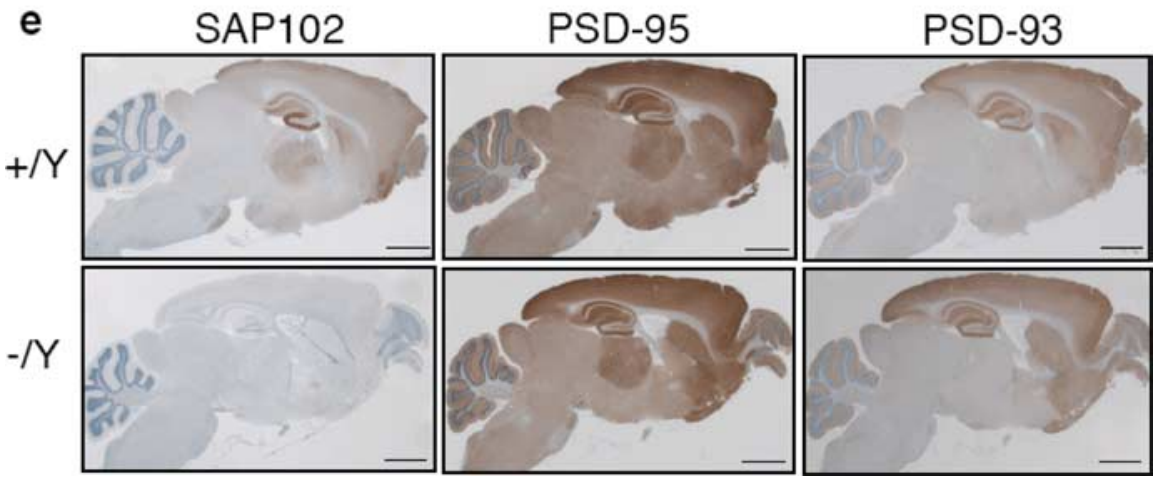

Figure 1. Generation of SAP102-targeted mice. $\boldsymbol{a}$, SAP102 has multiple protein-protein interaction domains, including three tandem PDZ (PSD-95/Discs large/zona occludens-1), an Src homology 3 (SH3), and a guanylate kinase (GK) domain (top). We replaced SAP102 exons 2-8 with a selection cassette in targeted mice, deleting the majority of the PDZ-coding sequence and creating a frame-shift mutation between exons 1 and 9 (middle and bottom). The $5^{\prime}$ probe outside the targeting region and primers P1-P3, used for Southern blot and PCR genotyping respectively, are shown. D, Dral restriction sites. $\boldsymbol{b}$, Southern blots of Dral-digested genomic DNA from wt $(+/ Y)$ and targeted $(-/ Y)$ ES cells, and wt, heterozygous $(+/-)$, and hemizygous $(-/ Y)$ mice confirm the structure of the mutant allele. c, PCR genotyping of targeted SAP102 mice using a common forward primer (P1) and separate reverse primers, P2 and P3, to amplify the wt and mutant alleles, respectively. $\boldsymbol{d}$, SAP102 is undetectable in Western blots of forebrain extract from hemizygous mutant mice. $\boldsymbol{e}$, Immunohistochemical staining shows loss of SAP102 throughout the brain of mutant mice. Expression patterns of other NMDA receptor-associated MAGUKs, PSD-95 and PSD-93, are unaffected. Immunohistochemical staining is brown, and hematoxylin counterstain is blue. Scale bars, $2 \mathrm{~mm}$.

To measure synaptic input/output functions, fiber volleys in Schaffer collateral axons and fEPSP slopes were measured at stimulation intensities that evoked fEPSPs corresponding to $25,50,75$, and $100 \%$ of the maximum fEPSP amplitude. AMPA receptor- and NMDA receptormediated components of EPSCs evoked at postsynaptic membrane potentials of -80 and $+40 \mathrm{mV}$ were estimated by measuring the amplitude of EPSCs at 5 and $50 \mathrm{~ms}$ after EPSC onset, respectively. For LTP, the 100 $\mathrm{Hz}$ stimulation protocol consisted of two trains of $100 \mathrm{~Hz}$ stimulation, each $1 \mathrm{~s}$ in duration and separated by $10 \mathrm{~s}$. The $5 \mathrm{~Hz}$ protocol consisted of a 3-min-long train of single presynaptic fiber stimulation pulses delivered at $5 \mathrm{~Hz}$ (900 pulses delivered in total). Pairing-induced LTP was elicited by pairing 100 pulses of presynaptic fiber stimulation (delivered at $10 \mathrm{~Hz}$ ) with a burst of three to four postsynaptic action potentials (APs) elicited by a $50 \mathrm{~ms}$ pulse of depolarizing current injection delivered $10 \mathrm{~ms}$ after EPSP onset.

\section{Results}

SAP102 null mice are viable and have normal brain structure

We generated SAP102 mutant mice by deleting $\mathrm{N}$-terminal exons and introducing a frame shift into the SAP102 gene on the mouse X chromosome (Fig. 1a). Southern blotting and PCR confirmed the structure of the altered locus in targeted ES cells and mice (Fig. 1b,c and data not shown). We analyzed SAP102 expression in $\mathrm{wt}(+/ \mathrm{Y}$, wt) and hemizygous ( $-/ \mathrm{Y}$, mutant, null) male mice using antibodies raised against the $\mathrm{N}$ terminus of the protein. No fulllength or truncated SAP102 protein could be detected in adult forebrain extracts from SAP102 mutant mice (Fig. $1 d$ and data not shown). Immunohistochemical staining showed robust expression of SAP102 in the hippocampus, cortex, and olfactory bulb of wt mice but complete absence in mutant mice, indicating that the mutation produces a null allele (Fig. 1e).

Consistent with the human condition (Tarpey et al., 2004), SAP102 mutant mice are viable and fertile. Crosses between heterozygous female and wt male mice produced heterozygous $(+/-)$ female, hemizygous $(-/ \mathrm{Y})$ male and wt mice of both sexes in the expected Mendelian ratios $\left(\chi^{2}\right.$ $=5.95 ; p=0.11)$. Crosses between hemizygous males and heterozygous females also produced Mendelian ratios of the expected offspring genotypes, including hemizygous males and homozygous $(-/-)$ females $\left(\chi^{2}=0.37 ; p=0.95\right)$. Several crosses between hemizygous male and homozygous female mice were also fertile, producing all-null litters of approximately normal size (data not shown). Brain sections stained histochemically with Nissl or immunohistochemically against PSD-95, PSD-93, NR1, NR2A, NR2B, or MAP2B showed no alterations in the morphology of the SAP102 mutant brain generally or the hippocampus in particular (data not shown) (supplemental Fig. 1, available at www.jneurosci.org as supplemental material). We found no change in neuronal cell density in hippocampal area CA1 or dentate gyrus (supplemental Fig. 2, available at www.jneurosci.org as supplemental material). Adult mutant mice displayed no gross physical or neurological abnormalities or overt seizures, and there was no difference between wt and hemizygous males in weaning body weight (data not shown). 


\section{SAP102 was required for normal spatial learning}

Because humans with SAP102 mutations show mental retardation, we assessed spatial learning and reference memory in the SAP102 mutant mice using a standard water maze protocol. Initial training used a visible platform to ensure that the mice can use visual cues to navigate to the platform. This was followed by hidden platform training in which the ability of the mice to use memory-guided navigation was tested (Fig. 2a). During the visible platform training, the platform was elevated above the water and curtains were drawn around the tank to eliminate extramaze spatial cues. We observed an interaction of day and genotype $\left(F_{(2,48)}=\right.$ 3.413; $p<0.0411$ ), and post hoc analysis showed that the mutant mice were faster on days 2 and 3 (with no difference between the two) compared with day 1 , whereas the wt mice did not improve over the $3 \mathrm{~d}$ (Fig. $2 b$, left). The mice were then trained for $5 \mathrm{~d}$ on a hidden platform task with extramaze cues present and a submerged platform (Fig. $2 b$, middle). The wt mice showed improvement over the $5 \mathrm{~d}$, but the mutants failed to improve $\left(F_{(4,100)}=\right.$ 3.059; $p<0.0201)$. Probe tests, in which the escape platform was removed from the pool, followed $10 \mathrm{~min}(\mathrm{H} 1)$ and $24 \mathrm{~h}(\mathrm{H} 2)$ after training. Performance did not differ between the two probe tests, so they were combined for additional analyses. Although no difference between the wt and knock-out mice was determined for combined probe trial $\left(\mathrm{H} 1+\mathrm{H} 2, F_{(1,26)}=2.915\right.$; $p<0.10$ ), the wt mice spent more time in the training quadrant than predicted by chance $\left(t_{(13)}>3.386 ; p<0.005\right)$, whereas the mutants did not $\left(t_{(12)}>1.1799 ; p<\right.$ 0.095).

We next examined flexibility of spatial learning using a reversal platform protocol, in which the hidden platform was switched to the opposite side of the pool (Fig. 2a). The path length decreased over the $5 \mathrm{~d}$ of reversal platform training (Fig. $2 b$, right) $\left(F_{(4,100)}=5.597 ; p<0.0004\right)$. There was no difference between the wt and mutant mice overall and no interaction of group and day, indicating that all mice were able to find the platform equally well. Memory for the platform was assessed throughout training using probe tests at the end of each day of reversal training (R1-R5) as well as $24 \mathrm{~h}$ and 1,2 , and 8 weeks after the last day of training (R6-R9).

The wt mice rapidly acquired the new platform position (Fig. $2 c$, R2-R9), performing above chance level from the first block of training $\left(\mathrm{R} 1+\mathrm{R} 2, t_{(13)}>2.272 ; p<0.041\right)$. In contrast, mutant mice performed no better than chance in the initial stages of training. They showed gradual improvement in their performance with training, eventually spending more time than chance in the target quadrant after completion of the $6 \mathrm{~d}$ training (R7, $\left.t_{(12)}>2.533 ; p<0.025\right)$. They then retained this information for an additional 2 weeks (better than chance, R8) but, by 8 weeks after training, were back to chance levels (R9). Direct comparison of the groups confirms that the mutant mice were impaired relative to the wt mice in the early stages of training $\left(\mathrm{R} 1+\mathrm{R} 2, F_{(1,25)}=\right.$ 4.534; $p<0.043)$ but that, with additional training, this deficit was alleviated (no group difference from R3+R4 onward). These results demonstrate that the SAP102 mutant mice are impaired in the initial stages of learning $(\mathrm{R} 1+\mathrm{R} 2)$ and that this impairment can be overcome by continued training $(\mathrm{H} 1+\mathrm{H} 2, \mathrm{R} 3+\mathrm{R} 4$, or $\mathrm{R} 5+\mathrm{R} 6)$. Together, these data indicate that, in the absence of SAP102, mice show a spatial learning impairment as tested in early learning, and this impairment can be overcome with continued training.

\section{Loss of SAP102 results in changes in spatial strategy usage}

Humans and animals, when confronted with problems, including spatial tasks, can choose among multiple strategies to achieve their goal (Wolfer et al., 1997; Graziano et al., 2003; Bohbot et al., 2004). Mice have been shown to use seven strategies for locating the platform in the water maze, and these can be correlated with 
a
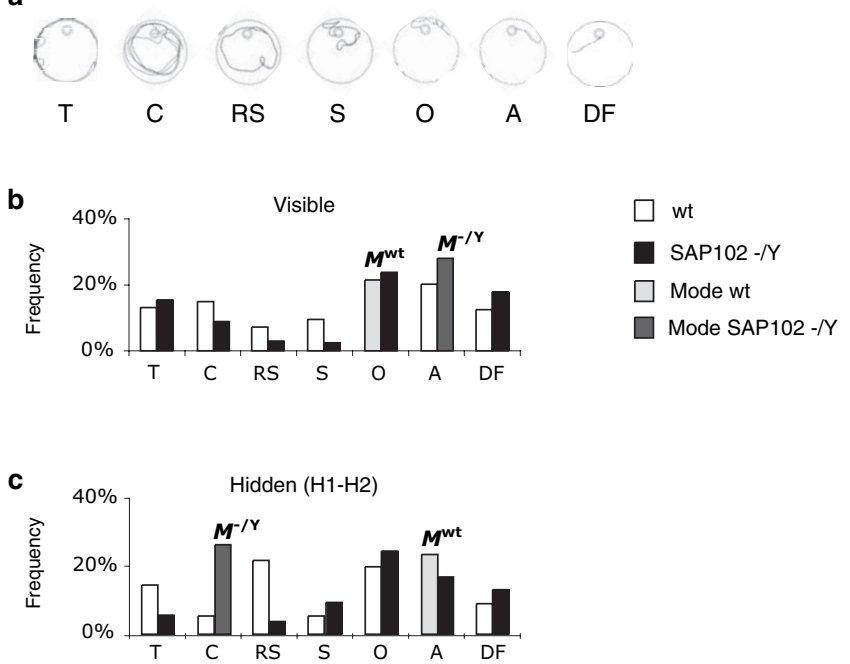

d
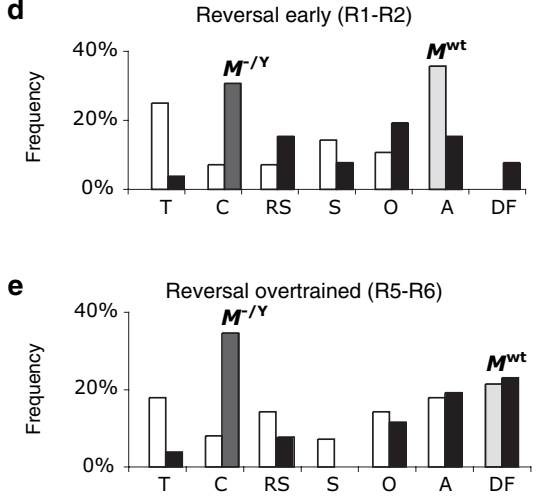

Figure 3. Strategy choices in the water maze. Shown are the percentages of wt and SAP $102^{-N}$ mice that choose a particular search strategy. $\boldsymbol{a}$, Sample traces of the paths for each of the seven search strategy categories. DF, Direct finding; $A$, approaching target; 0 , orienting; $S$, scanning; $R S$, random search; $C$, circling; $T$, thigmotaxic. $b$, Choices during the visible training trials. $c$, Choices for the first two probe trials $(\mathrm{H} 1+\mathrm{H} 2)$ after the initial training. $\boldsymbol{d}$, Choices for the early reversal probe trials $(R 1+R 2)$. $\boldsymbol{e}$, Choices for the reversal probe trials, analogous to the initial probe trials $(\mathrm{H} 1+\mathrm{H} 2)$. Modal choices $(\mathrm{M})$ are shown for wt and for SAP102 ${ }^{-/ \mathrm{Y}}$.

escape latency and ranked in order of increasing efficiency: thigmotaxis, circling, random search, scanning, self-orienting, approaching target, and direct finding (Graziano et al., 2003) (examples in Fig. $3 a$ ). To evaluate strategy usage, each individual swim trace for the visible and reversal probe trials was assigned to the seven categories. Although both mutants and wt used all of the strategies, their preferred (modal) strategies were different (Fig. $3 b-e, \mathrm{M}$ ). In the nonspatial, visible version of the task (Fig. $3 b$ ), the wt mice preferred the self-orienting strategy, and, surprisingly, the mutants used the more efficient approaching strategy. When the mice were placed in the hippocampus-dependent submerged platform tasks (hidden and reversal) (Fig. $3 c, d$ ), the wt mice used the approaching strategy, in contrast to the SAP102 mutants that used the less efficient circling strategy. With extended training, the control mice switched the most efficient, "direct finding" strategy (R5+R6), whereas the mutant mice stayed fixated on the circling strategy (Fig. 3e).

SAP102 and wt mice both use the approaching strategy but in the different tasks, indicating that both groups of animals are capable of using this strategy but deploy it under distinct conditions. Although approaching was optimal for the mutants in the visible platform, they did not use it to find the hidden platform This could arise if the mutants were unable to engage the approaching strategy when using spatial cues, either caused by an impairment in the cognitive processing of spatial information by NMDA receptor signaling or perhaps as a result of confounding factors attributable to sensorimotor, perceptual, or motivational defects.

To eliminate the possibility of confounds, we tested the mice in a secondary battery that included the assessment of motor coordination, muscle strength, and anxiety with the rotorod, grip strength, open-field exploration, and the elevated plus maze (data not shown) (supplemental Fig. 3, available at www. jneurosci.org as supplemental material). In the rotorod, no differences between the wt and mutant mice were detected at low or medium speeds. At the highest speed, the wt mice did not learn over days, whereas the mutant mice improved. There was no difference in grip strength detected. In the open field, there were no differences detected for time in the inner area, latency to reach the inner square, or stretch attend postures, but the mutant mice moved less as measured by line crosses, rearing, and the duration of time spent immobile. On the elevated plus maze, using the criterion defined by Weiss et al. (2000), differences need to be detected in four measures before an altered fear profile can be claimed (head dips, distance traveled, percentage time in open arms, and stretch attend postures). With these animals, there were no differences detected in the time spent in the open, stretch attend postures, or head dips, whereas the total distance traveled was lower for the mutants.

Overall, there are limited differences observed in this secondary battery, most of which show that the mutants had an altered locomotor phenotype. These differences, however, were not straightforward because, when motivation for a task was low (e.g., elevated plus maze or open-field exploration), the mutants' performance was worse than that of the wt mice, but when the motivation for the task was high, (e.g., rotorod or swimming in the water maze), the mutants performed as well or better than the wt mice. The essence of the secondary battery is twofold. First, there is no overall difference in the "anxiety/fear profile," and, second, there is no consistent deficit with motor coordination or strength. As a result, it is safe to conclude that the poorer performance observed by the mutants in the water maze was not attributable to increased fear or motoric phenotypes in the SAP102 mice. These data indicate that impaired learning performance in SAP102 mutants, although overcome by extended training, is ultimately achieved despite the use of suboptimal strategies.

\section{Normal basal synaptic transmission in SAP102 mutant mice}

Before assessing synaptic plasticity, we examined basic features of synaptic transmission. Because previous studies of PSD-95 and NMDA receptor knock-outs showed no major changes in basal synaptic transmission, we did not expect to find significant changes (Forrest et al., 1994; Sakimura et al., 1995; Kutsuwada et al., 1996; Tsien et al., 1996; Migaud et al., 1998). We first determined input-output functions for excitatory synaptic transmission at Schaffer collateral fiber inputs onto pyramidal cells in the hippocampal CA1 region. AMPA receptor-mediated synaptic transmission in slices from SAP102 mutant mice was normal (Fig. 4a), as was paired-pulse facilitation (Fig. $4 b$ ). The NMDA receptor-mediated component of EPSCs recorded using wholecell voltage-clamp techniques was not different in SAP102 mutant mice (Fig. 4c). SAP102 may have an important role in the trafficking of NR2B-containing NMDA receptors (Sans et al., 2000), and changes in the subunit composition of synaptic 
a

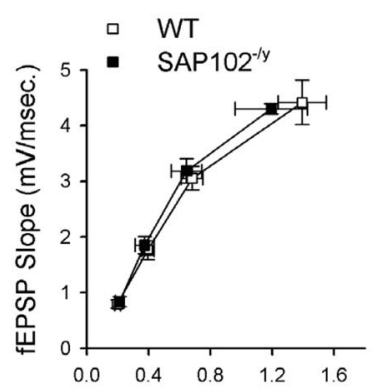

Fiber Volley Amplitude ( $\mathrm{mV}$ )

c
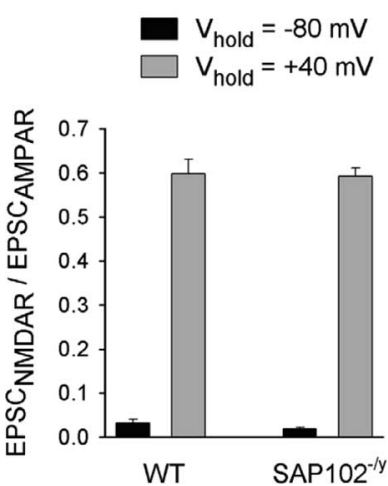

b

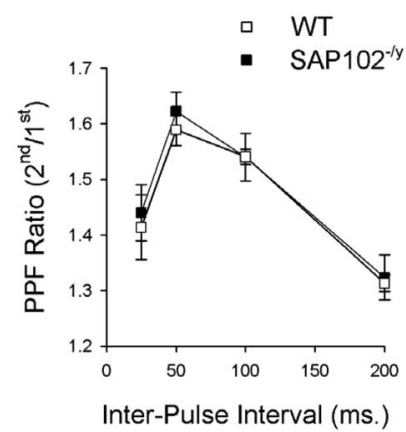

d
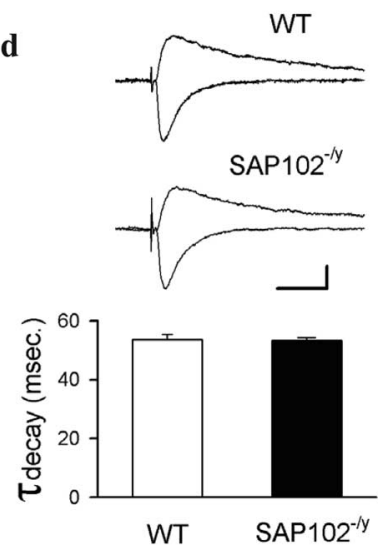

Figure 4. Basal synaptic transmission and postsynaptic receptor function are normal in SAP102 mutant mice. $\boldsymbol{a}$, The input- output curves for wt (open symbols; $n=5$ mice, 10 slices) and SAP102 mutant mice (filled symbols; $n=5$ mice, 8 slices) are shown. Presynaptic fiber volleys and postsynaptic fEPSP slopes were determined at four different stimulation intensities that elicited fEPSP s corresponding to $25,50,75$, and $100 \%$ of the maximum fEPSP amplitude. $\boldsymbol{b}$, Paired-pulse facilitation is normal in SAP102 mutant mice. c, NMDA receptor-mediated EPSCS are normal in SAP102 mutant mice. Whole-cell voltage-clamp techniques were used to record EPSPs at two different postsynaptic membrane potentials ( -80 and $+40 \mathrm{mV}$ ). NMDA receptor-mediated EPSCs (estimated from the EPSC amplitude $50 \mathrm{~ms}$ after EPSC onset) are expressed relative to the AMPA receptor-mediated component of the EPSC (estimated from the EPSC amplitude $5 \mathrm{~ms}$ after EPSC onset). There is no difference in EPSCs between wt (open bars; $n=15$ cells from 3 mice) and SAP102 mutants (filled bars; $n=22$ cells from 3 mice) at either membrane potential. The inset shows EPSCs recorded at -80 and $+40 \mathrm{mV}$ in wt and SAP102 mutant CA1 pyramidal cells. Calibration: $20 \mathrm{~ms}, 50 \mathrm{pA}$. $\boldsymbol{d}$, Comparison of single-exponential curves fitted to the decaying phase of the synaptic currents recorded at $+40 \mathrm{mV}$. No difference in the decay characteristics was observed between wt and SAP102 mutant mice.

NMDA receptors could alter the time course of NMDA receptormediated synaptic currents in SAP102 mutants. However, singleexponential curve fits to the decaying phase of EPSCs recorded at membrane potentials of $+40 \mathrm{mV}$ were also the same in CA1 pyramidal cells from SAP102 and wt mice (Fig. $4 d$ ). This suggests that there is not a decrease in NR2B-containing NMDA receptors at synapses in adult SAP102 mutant mice but does not rule out a role for SAP102 at earlier time points in development in which SAP102 is expressed at higher levels (Sans et al., 2000). Together, these results indicate that AMPA and NMDA receptor-mediated synaptic transmission is normal at Schaffer collateral fiber inputs to the hippocampal CA1 region of adult SAP102 mutant mice.

\section{Altered LTP and spike-timing-dependent plasticity in SAP102 mutants}

We next examined the issue that different patterns of synaptic activity, which lead to changes in synaptic strength, might use MAGUK proteins. Because PSD-95 mutants showed abnormal

a

$100 \mathrm{~Hz}$

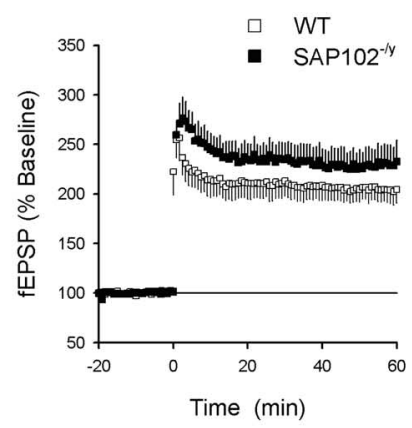

c

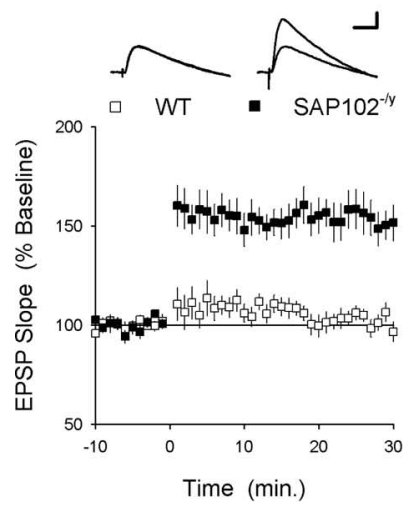

b

$5 \mathrm{~Hz}$

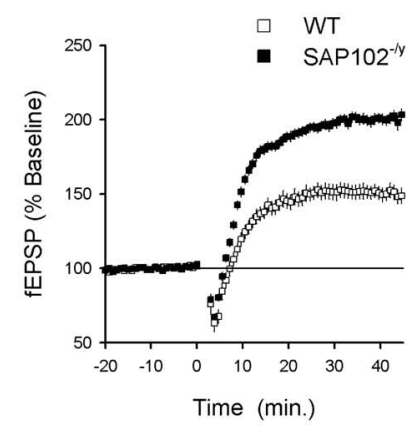

d Burst Pair

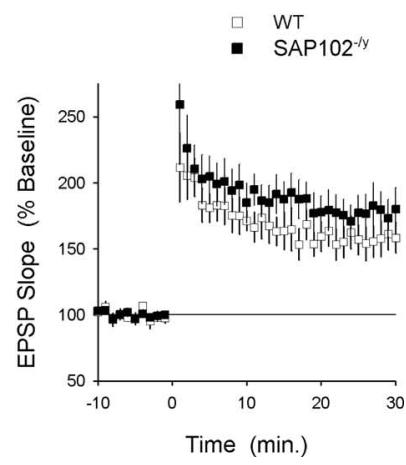

Figure 5. Loss of SAP102 results in specific enhancement of hippocampal synaptic plasticity induced by theta frequency and spike timing-dependent stimulation. $\boldsymbol{a}$, High-frequency stimulation-induced LTP is normal in SAP102 mutants. Sixty minutes after $100 \mathrm{~Hz}$ stimulation (2 trains, each of $1 \mathrm{~s}$ duration, delivered at time $=0$ ) fEPSPs were potentiated to $204 \pm 13 \%$ of baseline in wt slices ( $n=5$ mice, 8 slices) and were potentiated to $230 \pm 20 \%$ of baseline in SAP102 mutant slices ( $n=4$ mice, 9 slices; not significant compared with control, $p=0.28$ ). $\boldsymbol{b}$, Low-frequency stimulation (900 pulses at $5 \mathrm{~Hz}$ ) induces modest LTP in wt animals (fEPSPs potentiated to $150 \pm 5 \%$ of baseline; $n=8,15$ slices) but significantly enhanced LTP in SAP102 ${ }^{-N}$ slices ( $201 \pm 4 \%$ of baseline; $n=6$ mice, 16 slices; $p<0.005$ ). c, Single postsynaptic APs paired with single pulses of presynaptic fiber stimulation fails to induce LTP in wt pyramidal cells but induces robust LTP in SAP102 ${ }^{-N}$ cells. Pairing (100 paired stimulations delivered at $10 \mathrm{~Hz}$ with pre/post interval of $10 \mathrm{~ms}$ ) was delivered at time $=0$. Inset shows superimposed EPSPs recorded during baseline and $30 \mathrm{~min}$ after pairing in a pyramidal cell from a wt (left) and a SAP102 ${ }^{-N}$ (right) mouse. $d$, Bursts of postsynaptic APs paired with presynaptic fiber stimulation induce similar amounts of LTP in wt and SAP102 ${ }^{-N}$ mutant cells. EPSPs were paired with bursts of three to four postsynaptic action potentials elicited by a $50 \mathrm{~ms}$ depolarizing current pulse delivered via the recording electrode.

LTP over a wide range of stimulation conditions, we were particularly interested to ask whether SAP102 was required over the same wide range or, more interestingly, might have a requirement in more specific ranges of synaptic activity. Thus, we examined the ability of several different stimulation protocols to induce LTP in the CA1 region of hippocampal slices from SAP102 mutant mice. As shown in Figure $5 a$, the induction of LTP by a conventional high-frequency stimulation protocol (two trains of $100 \mathrm{~Hz}$ stimulation) was normal in SAP102 mutant mice. In contrast, a long, low-frequency $(5 \mathrm{~Hz})$ train of synaptic stimulation that induced only modest LTP in wt slices induced a twofold increase in synaptic strength in slices obtained from SAP102 mutants $(p<0.005$ compared with wt) (Fig. $5 b$ ). This is in stark contrast to PSD-95 mutants, which showed significant increases in LTP in both stimulation paradigms.

We then examined the response of excitatory synapses in the 
hippocampal CA1 region to spike timing-dependent plasticity protocols, a more physiologically relevant paradigm (Thomas et al., 1998; Meredith et al., 2003). In wt cells, pairing of single pulses of presynaptic fiber stimulation with a burst of postsynaptic APs induced robust LTP, whereas pairing with single postsynaptic APs did not (Fig. $5 c, d$ ). This is consistent with previously published data and demonstrates that AP bursts are the essential trigger for LTP induction in these cells. Remarkably, however, in SAP102 mutant cells, pairing with single postsynaptic APs induced robust LTP $($ Fig. $5 c)$. This indicates that SAP102 plays an instrumental role in determining the rules governing how changes in synaptic strength are induced by coincident presynaptic and postsynaptic activity. Such inappropriate induction of LTP could result in degradation of information storage, producing the learning deficits observed in the SAP102 mutant mice. Moreover, in whole-cell current-clamp experiments, we found that pairing EPSPs with bursts of postsynaptic action potentials (100 pairings at $10 \mathrm{~Hz}$ ) induced similar levels of LTP in cells from wt and SAP102 mutant mice (Fig. 5d). We conclude that SAP102 was not required for normal synaptic transmission but was necessary for frequency-specific forms of LTP and in particular that form of LTP induced by low-frequency $(5 \mathrm{~Hz})$ patterns of synaptic activity.

\section{SAP102 couples NMDA receptors to the MAPK/ERK pathway} The electrophysiological specificity of the LTP phenotype provides an important clue toward the identification of the downstream signaling pathway that must be altered in SAP102 mutants, namely, that the enzyme(s) involved must be selective for 5 $\mathrm{Hz}$ and not $100 \mathrm{~Hz}$ LTP. Previous studies show that MAP kinase kinase (MEK)/ERK signaling has precisely this property because MEK inhibitors preferentially block $5 \mathrm{~Hz}$ but not $100 \mathrm{~Hz}$ LTP in mouse CA3-CA1 slices (Winder et al., 1999). Although this suspicion was subsequently confirmed, we initially took a less biased approach using proteomic assays that measure the function of many different kinases. This differential proteomics strategy examined the levels and/or phosphorylation of 48 different postsynaptic proteins from the hippocampus of mutant mice (Fig. $6 a$ and data not shown) (for a full list of phosphorylation sites, see supplemental Materials and Methods, available at www. jneurosci.org as supplemental material). Strikingly, these studies showed a change in only one protein: the phosphorylated form of ERK2 (phospho-ERK). Elevation of phospho-ERK in SAP102 mutants was confirmed using Western blotting (Fig. 6b) and ELISA assays (Fig. $6 c$ ), in which a modest $(\sim 25 \%)$ but consistently reproducible increase in basal phospho-ERK was seen in the mutant mice. Consistent with the idea that these changes in basal ERK activity contribute to the enhancement of LTP in SAP102 mutants, the MEK inhibitor U0126 [1,4-diamino-2,3dicyano-1,4-bis(o-aminophenylmercapto)butadiene] blocked the enhancement of $5 \mathrm{~Hz}$ stimulation-induced LTP in SAP $102^{-/ y}$ slices (Fig. 6d).

We next examined NMDA receptor activation of ERK and other members of the ERK pathway. Hippocampal slices from wt and mutant mice were stimulated by application of NMDA (20 $\mu \mathrm{M}$ for $3 \mathrm{~min}$ ), and protein phosphorylation and levels were analyzed. In electrophysiological experiments using the same NMDA treatment, we found that NMDA had no lasting effects on synaptic transmission in wt slices and induced a significant but transient potentiation of synaptic transmission in slices from SAP $102^{-/ y}$ mice (data not shown). Figure $6 e$ shows that ERK phosphorylation, normalized between wt and SAP $102^{-/ Y}$ levels at the time of stimulation, was attenuated in response to NMDA

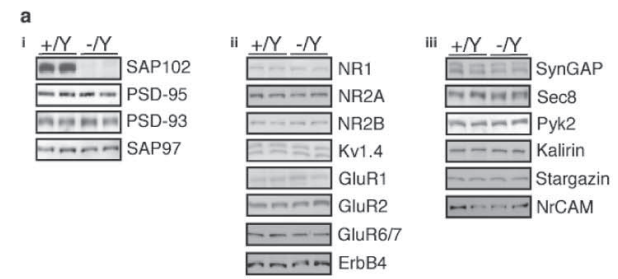

b

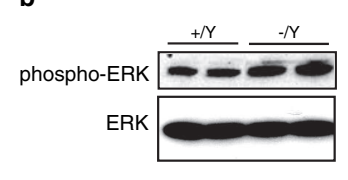

e

c

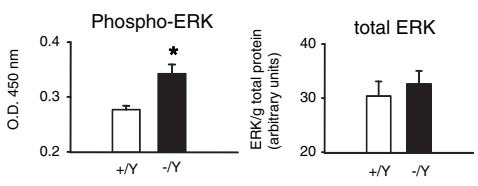

$\mathbf{f}$
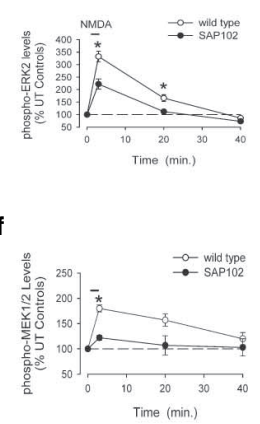

d
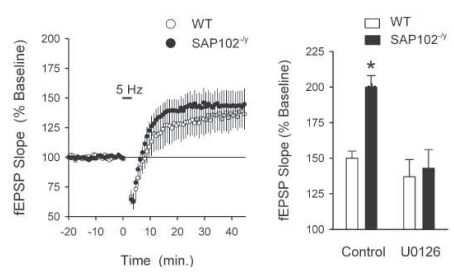

g
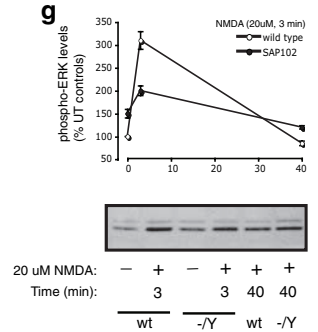

Figure 6. Altered postsynaptic signaling in SAP102 mutant mice. $\boldsymbol{a}$, No change in total hippocampal levels of postsynaptic proteins in mutant mice. $\boldsymbol{i}$, MAGUKs; $\boldsymbol{i}$, postsynaptic receptors; iii, postsynaptic signaling proteins. $\boldsymbol{b}$, Elevated basal ERK phosphorylation in SAP102 mutant mice. Western blotting of hippocampal protein extracts with an antibody against phosphoERK shows a consistent elevation of the phosphorylated form of the protein with no change in total ERK levels. Representative samples from $15 \mathrm{wt}$ and 15 SAP $102^{-/ Y}$ animals are shown. c, A sandwich ELISA assay confirms the increase in ERK phosphorylation $\left(t_{(17)}=3.38 ; p=0.003\right.$ ) without a change in total ERK $\left(t_{(23)}<1\right.$; NS). $\boldsymbol{d}$, The MEK inhibitor U0126 blocks the enhancement of LTP in SAP102 mutant mice. Slices were continuously bathed in ACSF containing $20 \mu \mathrm{m}$ U0126. fEPSPs were potentiated to $137 \pm 12 \%$ of baseline in wt slices (open symbols; $n=4$ ) and $143 \pm 12 \%$ of baseline in slices from SAP102 mutant mice (filled symbols; $n=5 ; p=0.76$ compared with wt). The histogram on the right shows the magnitude of LTP measured $45 \mathrm{~min}$ after theta pulse stimulation in wt and SAP102 mutant slices under control conditions and in the presence of U0126. $\boldsymbol{e}$, Phospho-ERK response to NMDA stimulation is attenuated in SAP102 mutant mice. NMDA was bath applied to hippocampal slices, and phospho-ERK was analyzed by Western blotting. SAP102 ${ }^{-/ Y}$ levels at time $=0$ are normalized to those of wt slices. PhosphoERK levels in $-/ Y$ slices are reduced compared with wt 5 min and 20 min after stimulation. Asterisks indicate statistically significant differences. $f$, Increase in phospho-MEK is also attenuated in response to NMDA application. $\boldsymbol{g}$, Independent experiments without normalization of wt and SAP102 ${ }^{-/ Y}$ levels at time $=0$ show that phospho-ERK response to NMDA stimulation is attenuated notwithstanding its basal elevation.

stimulation in the absence of SAP102. The response to phosphoMEK1/2, the upstream activator of ERK in the MAPK pathway, was also attenuated (Fig. $6 f$ ), although basal phospho-MEK1/2 levels were unaltered. To confirm that the attenuated phosphoERK response was not an artifact resulting from normalization of the SAP $102^{-/ Y}$ levels to that of wt, we performed additional independent experiments without normalization. We found an $\sim 30 \%$ reduction in phospho-ERK levels in mutant slices compared with wt after NMDA application despite elevated basal phospho-ERK (Fig. 6g). These results show that SAP102 regulates MAPK-mediated NMDA receptor signaling.

Although MEK and ERK have been extensively characterized 


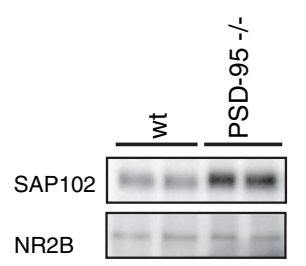

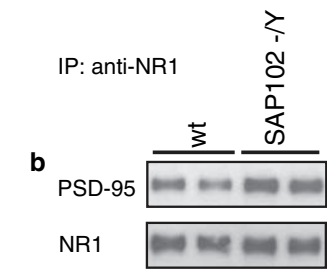

C

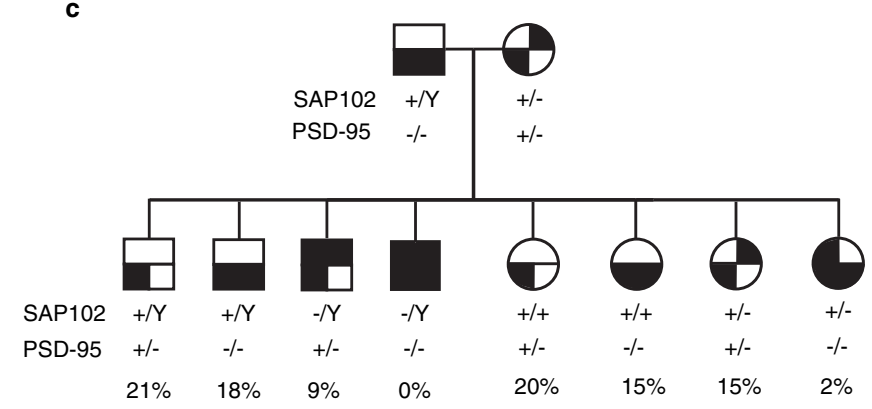

Figure 7. Overlapping but distinct functional roles of SAP102 and PSD-95. a, SAP102 protein expression is elevated in the hippocampus of PSD-95 mutant mice. Shown are Western blots on hippocampal extracts from wt and PSD-95 homozygous animals. $\boldsymbol{b}$, Increased PSD-95 associated with NMDARs in SAP102 mutant mice. The NMDA receptor complex was immunoprecipitated (IP) from whole forebrain extracts with an NR1 antibody and then blotted with PSD-95. Both $\boldsymbol{a}$ and $\boldsymbol{b}$ show representative results from $10 \mathrm{wt}$ and 10 mutant animals. C, SAP102 and PSD-95 double mutation is lethal. Crosses between SAP102 and PSD-95 mutant mice produced a very low proportion of female PSD-95 ${ }^{-1-}$ mice, SAP102 ${ }^{+/-}$mice, and no male double knock-outs. $A \chi^{2}$ test for goodness of fit shows that the distribution of offspring genotypes is severely skewed $\left(\chi^{2}=34.4 ; n=88 ; p=0.0001\right)$.

in the context of the induction of LTP, the physiologically relevant substrates remain less well understood. We attempted to discover the downstream effects of the altered ERK activity in SAP102 mutants by ERK substrates for which reagents were available. We found no change in phosphorylation of $\mathrm{K}_{\mathrm{v}} 4.2$, Elk-1, pS383, p70, ribosomal S6 kinase-4 (RSK-4), or Menkes protein MNK-1 (data not shown). It is thus likely that the downstream alteration is mediated by some other, as yet undescribed, ERK substrate.

\section{SAP102 and PSD-95 perform distinct but overlapping functions}

SAP102 and PSD-95 have similar protein domains, binding partners, subcellular localization, and regional expression patterns (Cho et al., 1992; Muller et al., 1996; Fukaya and Watabe, 2000), suggesting they may have overlapping and specific functions. The availability of knock-outs of both genes allows a genetic approach to this issue. We first asked whether SAP102 expression was altered in PSD-95 mutant mice. Western blots of hippocampal extracts from $10 \mathrm{wt}$ and 10 mutant animals showed a robust and reproducible elevation of SAP102, suggesting some compensation for loss of PSD-95 in these mice (Fig. 7a). We had already found no change in PSD-95 protein levels in hippocampus extracts of SAP102 mice (Fig. 6a), but a change in PSD-95 localization to the NMDA receptor complex was another possible compensatory mechanism. We used coimmunoprecipitation to examine the levels of PSD-95 associated with NMDARs in SAP102 mutants. We found that more PSD-95 coimmunoprecipitated with NR1 in forebrain extracts from 10 SAP102 mutant mice than from 10 of their wt littermates (Fig. $7 b$ ). These results suggest that PSD-95 and SAP102 can be recruited to the same NMDA receptor complexes and may compete for interaction. Moreover, these results suggest that SAP102 and PSD-95 have partial functional overlap and that the phenotypes observed in the two mutant mouse strains may be tempered by compensation by the other MAGUK. If this was the case, mice with mutations in both proteins should display a more severe phenotype than that of the individual mutations. To examine this prediction, we crossed the SAP102 and PSD-95 strains. Of 88 weaned pups from these crosses, none were double null, and only two females were heterozygous for SAP102 and homozygous for PSD-95, reflecting a severely skewed distribution of genotypes among the offspring (Fig. $7 c$ ). Additional analysis indicated that the double-mutant mice die perinatally, with $4 \%$ of pups being double knock-out at birth (compared with an expected 12.5\%) and none surviving past postnatal day 3. These data show that SAP102 and PSD-95 have partial function overlap and that the presence of at least one is necessary for postnatal survival.

\section{Discussion}

This study shows that NMDA receptor-driven plasticity, behavior, and signal transduction is mediated by the MAGUK protein SAP102. SAP102 was required for the induction or initiation of these signaling events consistent with its direct physical association with the receptor. Remarkable specificity in the signaling responses was observed, with only specific frequencies of synaptic activation requiring SAP102 and ERK pathways. Thus, the discrimination of different patterns of neuronal activity, all of which activate the NMDA receptor, is performed by distinct MAGUK proteins that then selectively engage downstream pathways. These results are consistent with published experiments showing MAGUK selectivity in relation to NMDA receptor subunits, downstream signaling, and plasticity effector mechanisms. Biochemical and electrophysiological evidence suggests that PSD-95 preferentially associates with NR2A-containing NMDA receptors, whereas SAP102 associates with NR2B-containing receptors (Sans et al., 2000). NR2B-SAP102 complexes may inhibit the ERK/MAPK pathway, through synaptic Ras-GTPase-activating protein, to facilitate withdrawal of AMPA receptors from the postsynaptic membrane, whereas NR2A-PSD-95 complexes have the opposite effect (Kim et al., 2005).

Consistent with the notion that SAP102 may have an important role in coupling NMDA receptors to the ERK pathway, basal levels of activated ERK are elevated in the hippocampus of SAP012 $2^{-/ y}$ mice, and the enhancement of $5 \mathrm{~Hz}$ stimulationinduced LTP in slices from SAP $102^{-/ y}$ was blocked by MEK inhibitors. Moreover, the induction of LTP by spike timingdependent plasticity induction protocols, which is known to be dependent on ERK activation (Watanabe et al., 2002), was enhanced in SAP102 mutant mice. Importantly, ERK activation is thought to facilitate the induction of spike-timing-dependent LTP by downregulating dendritic potassium channels (Watanabe et al., 2002). However, we did not see a difference in the magnitude of the depolarizing current pulse needed to generate action potentials in SAP102 compared with wt cells (data not shown). Although this suggests that the ability of synapses in SAP $102^{-/ y}$ mice to undergo LTP in response to EPSPs paired with single postsynaptic APs is not attributable to changes in neuronal excitability, it does not rule out the possibility that subtle changes in dendritic excitability might be involved and thus future experiments will be needed to address this possibility. Surprisingly, although the increase in basal levels of ERK activation in SAP $102^{-/ y}$ mutants is consistent with the results from our elec- 
trophysiological studies showing that ERK-dependent forms of plasticity are enhanced in SAP102 mutants, we also found that NMDA-induced activation of the ERK pathway was suppressed in SAP102 mutants. It therefore seems likely that the elevated levels of basal ERK activity in SAP $102^{-/ y}$ mice produce changes in downstream signaling pathways that have priming or metaplastic effects that facilitate LTP induction.

Selectivity in signal processing conferred by MAGUK proteins is a property that is likely to be important in pathological and physiological circumstances. SAP102 is not expressed in all synapses and is expressed at different times in development to PSD-95 (Sans et al., 2000). Clearly, the absence of SAP102 in the adult mouse and human is deleterious, as shown by the impairments in learning in both species. This requirement in mammals for SAP102 is likely to be a vertebrate specialization because invertebrates (including Aplysia californica, Drosophila melanogaster, and Caenorhabditis elegans) have only one dlg gene. Thus, it appears that the evolutionary expansion of the MAGUK family has provided diversity in signaling in mammals and at the same time provided a genetic vulnerability to mental illness.

These mouse genetic studies give insights into the evolution and organization of signaling proteins and the role postsynaptic complexes play in specific aspects of cognition. Classic psychological studies of information processing have defined a diverse repertoire of features that together comprise cognitive functions (James, 1890; Wilson and Keil, 1999). Among these are learning, memory, attention, perception, strategies, and planning, all of which are important in the organism's ability to adapt to a changing environment. Our data show that a genetic manipulation in the mouse can bias the processing of information so as to affect which strategies are adopted in different forms of learning. The SAP102 mutants exhibited impairments in learning hippocampus-dependent and NMDA receptor-dependent spatial tasks. Closer inspection of their choice of escape strategy in the spatial and nonspatial learning tasks revealed that the SAP102 mutation influenced the use of strategy. A less efficient strategy was used in the spatial task, which, despite training and overall improvement in task performance, was maintained. The inability to use the optimal spatial strategy comes at the expense of faster swimming over longer routes. In the nonspatial task, the mutants used the same strategy as that used by the wt mice in the spatial task. Surprisingly, this strategy used by the mutants in the visible platform task was a more efficient strategy than that used by the wt mice in this task. These results indicate that the mutation leads to an altered deployment of strategy in different behavioral settings. These data are more consistent with an impairment in the engagement of those strategies rather than in strategy formulation or utilization per se. As exemplified here in these spatial and nonspatial strategies, multiple cognitive systems are often available to animals for dealing with particular tasks. This redundancy and overlap, even competition among different strategies, is likely to be more prevalent in humans in which attention to visual stimuli is the result of the competition between selectivity and the limited capacity for processing information within the CNS (Desimone and Duncan, 1995). It is notable that children with diseases of human cognition such as autism or Asperger's disorder excel in some perceptual tasks as a result of the strategies made available to them by their deficits (O'Riordan and Plaisted, 2001).

Our observations of SAP102 function may be directly relevant to the mechanisms of autism because MAGUK proteins in the NMDA receptor complex bind directly to neuroligin, an autism susceptibility gene (Irie et al., 1997; Yan et al., 2004). In addition to neuroligin, the immediate pathways involving SAP102 and ERK include other genes on the $\mathrm{X}$ chromosome, two of which have been shown to underlie human cognitive impairment: fragile X mental retardation protein (Siomi et al., 1993; Todd et al., 2003), which regulates PSD-95 (K. S. Dickson, C. Bagni, and S. G. N. Grant, unpublished observations), and RSK, which is downstream of ERK (Trivier et al., 1996). SAP102, ERK, RSK, and neuroligin have been reported in NRC/MAGUK-associated signaling complexes (MASC), indicating that these complexes are a common target for X-linked cognitive impairments. We predict that additional genetic dissection of NRC/MASC in mouse and humans should uncover novel mechanisms of cognition and its disorders.

\section{References}

Bohbot VD, Iaria G, Petrides M (2004) Hippocampal function and spatial memory: evidence from functional neuroimaging in healthy participants and performance of patients with medial temporal lobe resections. Neuropsychology 18:418-425.

Chen L, Chetkovich DM, Petralia RS, Sweeney NT, Kawasaki Y, Wenthold RJ, Bredt DS, Nicoll RA (2000) Stargazin regulates synaptic targeting of AMPA receptors by two distinct mechanisms. Nature 408:936-943.

Cho KO, Hunt CA, Kennedy MB (1992) The rat brain postsynaptic density fraction contains a homolog of the drosophila discs-large tumor suppressor protein. Neuron 9:929-942.

Desimone R, Duncan J (1995) Neural mechanisms of selective visual attention. Annu Rev Neurosci 18:193-222.

Emptage N, Bliss TV, Fine A (1999) Single synaptic events evoke NMDA receptor-mediated release of calcium from internal stores in hippocampal dendritic spines. Neuron 22:115-124.

Fagiolini M, Katagiri H, Miyamoto H, Mori H, Grant SG, Mishina M, Hensch TK (2003) Separable features of visual cortical plasticity revealed by $N$-methyl-D-aspartate receptor 2A signaling. Proc Natl Acad Sci USA 100:2854-2859.

Firestein B, Brenman J, Aoki C, Sanchez-Perez A, El-Husseini A, Bredt D (1999) Cypin: a cytosolic regulator of PSD-95 postsynaptic targeting. Neuron 24:659-672.

Forrest D, Yuzaki M, Soares HD, Ng L, Luk DC, Sheng M, Stewart CL, Morgan JI, Connor JA, Curran T (1994) Targeted disruption of NMDA receptor 1 gene abolishes NMDA response and results in neonatal death. Neuron 13:325-338.

Fukaya M, Watabe AM (2000) Improved immunohistochemical detection of postsynaptically located PSD-95/SAP90 protein family by protease section pretreatment: a study in the adult mouse brain. J Comp Neurol 426:572-586.

Garry EM, Moss A, Delaney A, O’Neill F, Blakemore J, Bowen J, Husi H, Mitchell R, Grant SG, Fleetwood-Walker SM (2003) Neuropathic sensitization of behavioral reflexes and spinal NMDA receptor/CaM kinase II interactions are disrupted in PSD-95 mutant mice. Curr Biol 13:321-328.

Grant SG, Marshall MC, Page KL, Cumiskey MA, Armstrong JD (2005) Synapse proteomics of multiprotein complexes: en route from genes to nervous system diseases. Hum Mol Genet 14 [Spec No 2]:R225-R234.

Graziano A, Petrosini L, Bartoletti A (2003) Automatic recognition of explorative strategies in the Morris water maze. J Neurosci Methods 130:33-44.

Husi H, Ward MA, Choudhary JS, Blackstock WP, Grant SGN (2000) Proteomic analysis of NMDA receptor-adhesion protein signaling complexes. Nat Neurosci 3:661-669.

Irie M, Hata Y, Takeuchi M, Ichtchenko K, Toyoda A, Hirao K, Takai Y, Rosahl TW, Sudhof TC (1997) Binding of neuroligins to PSD-95. Science 277:1511-1515.

James W (1890) The principles of psychology. London: Macmillan.

Kim E, Cho KO, Rothschild A, Sheng M (1996) Heteromultimerization and NMDA receptor-clustering activity of chapsyn-110, a member of the PSD-95 family of proteins. Neuron 17:103-113.

Kim E, Naisbitt S, Hsueh Y-P, Rao A, Rothschild A, Craig AM, Sheng M (1997) GKAP, a novel synaptic protein that interacts with the guanylate kinase-like domain of the PSD-95/SAP90 family of channel clustering molecules. J Cell Biol 136:669-678.

Kim JH, Liao D, Lau LF, Huganir RL (1998) SynGAP: a synaptic RasGAP 
that associates with the PSD-95/SAP90 protein family. Neuron 20:683-691.

Kim MJ, Dunah AW, Wang YT, Sheng M (2005) Differential roles of NR2Aand NR2B-containing NMDA receptors in Ras-ERK signaling and AMPA receptor trafficking. Neuron 46:745-760.

Komiyama NH, Watabe AM, Carlisle HJ, Porter K, Charlesworth P, Monti J, Strathdee DJC, O'Carroll CM, Martin SJ, Morris RGM, O’Dell TJ, Grant SGN (2002) SynGAP regulates ERK/MAPK signaling, synaptic plasticity and learning in the complex with postsynaptic density 95 and NMDA receptor. J Neurosci 22:9721-9732.

Kornau HC, Schenker LT, Kennedy MB, Seeburg PH (1995) Domain interaction between NMDA receptor subunits and the postsynaptic density protein PSD-95. Science 269:1737-1740.

Kutsuwada T, Sakimura K, Manabe T, Takayama C, Katakura N, Kushiya E, Natsume R, Watanabe M, Inoue Y, Yagi T, Aizawa S, Arakawa M, Takahashi H, Nakamura K, Mori H, Mishina M (1996) Impairment of suckling response, trigeminal neuronal pattern formation and hippocampal LTD in NMDA receptor $\varepsilon 2$ subunit mutant mice. Neuron 16:333-344.

Lau LF, Mammen A, Ehlers MD, Kindler S, Chung WJ, Garner CC, Huganir RL (1996) Interaction of the $N$-methyl-D-aspartate receptor complex with a novel synapse-associated protein, SAP102. J Biol Chem 271:21622-21628.

Makino K, Kuwahara H, Masuko N, Nishiyama Y, Morisaki T, Sasaki J, Nakao M, Kuwano A, Nakata M, Ushio Y, Saya H (1997) Cloning and characterization of NE-dlg: a novel human homolog of the Drosophila discs large ( $\mathrm{dlg}$ ) tumor suppressor protein interacts with the APC protein. Oncogene 14:2425-2433.

Masuko N, Makino K, Kuwahara H, Fukunaga K, Sudo T, Araki N, Yamamoto H, Yamada Y, Miyamoto E, Saya H (1999) Interaction of $\mathrm{NE}-\mathrm{dlg} / \mathrm{SAP} 102$, a neuronal and endocrine tissue-specific membraneassociated guanylate kinase protein, with calmodulin and PSD-95/SAP90. A possible regulatory role in molecular clustering at synaptic sites. J Biol Chem 274:5782-5790.

Meredith RM, Floyer-Lea AM, Paulsen O (2003) Maturation of long-term potentiation induction rules in rodent hippocampus: role of GABAergic inhibition. J Neurosci 23:11142-11146.

Migaud M, Charlesworth P, Dempster M, Webster LC, Watabe AM, Makhinson M, He Y, Ramsay MF, Morris RGM, Morrison JH, O’Dell TJ, Grant SGN (1998) Enhanced long-term potentiation and impaired learning in mice with mutant postsynaptic density-95 protein. Nature 396:433-439.

Montgomery JM, Zamorano PL, Garner CC (2004) MAGUKs in synapse assembly and function: an emerging view. Cell Mol Life Sci 61:911-929.

Muller BM, Kistner U, Kindler S, Chung WJ, Kuhlendahl S, Fenster SD, Lau LF, Veh RW, Huganir RL, Gundelfinger ED, Garner CC (1996) SAP102, a novel postsynaptic protein that interacts with NMDA receptor complexes in vivo. Neuron 17:255-265.

O'Riordan M, Plaisted K (2001) Enhanced discrimination in autism. Q J Exp Physiol 54A:961-979.

Penzes P, Johson RC, Sattler R, Zhang X, Huganir RL, Kambampati V, Mains RE, Eipper BA (2001) The neuronal Rho-GEF kalirin-7 interacts with PDZ domain-containing proteins and regulates dendritic morphogenesis. Neuron 29:229-242.

Sakimura K, Kutsuwada T, Ito I, Manabe T, Takayama C, Kushiya E, Yagi T, Aizawa S, Inoue Y, Sugiyama H, Mishina M (1995) Reduced hippocampal LTP and spatial learning in mice lacking NMDA receptor $\varepsilon 1$ subunit. Nature 373:151-155.
Sans N, Petralia RS, Wang YX, Blahos II J, Hell JW, Wenthold RJ (2000) A developmental change in NMDA receptor-associated proteins at hippocampal synapses. J Neurosci 20:1260-1271.

Sans N, Prybylowski K, Petralia RS, Chang K, Wang Y-X, Racca C, Vicini S, Wenthold RJ (2003) NMDA receptor trafficking through an interaction between PDZ proteins and the exocyst complex. Nat Cell Biol 5:520-530.

Seabold GK, Burette A, Lim IA, Weinberg RJ, Hell JW (2003) Interaction of the tyrosine kinase Pyk2 with the $N$-methyl-D-aspartate receptor complex via the Src homology 3 domains of PSD-95 and SAP102. J Biol Chem 278:15040-15048.

Siomi H, Siomi MC, Nussbaum RL, Dreyfuss G (1993) The protein product of the fragile $\mathrm{X}$ gene, FMR1, has characteristics of an RNA-binding protein. Cell 74:291-298.

Takeuchi M, Hata Y, Hirao K, Toyoda A, Irie M, Takai Y (1997) A family of PSD-95/SAP90-associated proteins localized at postsynaptic density. J Biol Chem 272:11943-11951.

Tarpey P, Parnau J, Blow M, Woffendin H, Bignell G, Cox C, Cox J, Davies H, Edkins S, Holden S, Korny A, Mallya U, Moon J, O’Meara S, Parker A, Stephens P, Stevens CF, Teague J, Donnelly A, Mangelsdorf M, et al. (2004) Mutations in the DLG3 gene cause non-syndromic X-linked mental retardation. Am J Hum Genet 75:318-324.

Thomas MJ, Watabe AM, Moody TD, Makhinson M, O’Dell TJ (1998) Postsynaptic complex spike bursting enables the induction of LTP by theta frequency synaptic stimulation. J Neurosci 18:7118-7126.

Todd PK, Mack KJ, Malter JS (2003) The fragile X mental retardation protein is required for type-I metabotropic glutamate receptor-dependent translation of PSD-95. Proc Natl Acad Sci USA 100:14374-14378.

Trivier E, De Cesare D, Jacquot S, Pannetier S, Zackai E, Young I, Mandel J-L, Sassone-Corsi P, Hanauer A (1996) Mutations in the kinase Rsk-2 associated with Coffin-Lowry syndrome. Nature 384:567-570.

Tsien JZ, Huerta PT, Tonegawa S (1996) The essential role of hippocampal CA1 NMDA receptor-dependent synaptic plasticity in spatial memory. Cell 87:1327-1338.

Watanabe S, Hoffman DA, Miogliore M, Johnston D (2002) Dendritic K+ channels contribute to spike-timing dependent long-term potentiation in hippocampal pyramidal neurons. Proc Natl Acad Sci USA 99:8366-8371.

Weiss SM, Lightowler S, Stanhope KJ, Kennett GA, Dourish CT (2000) Measurement of anxiety in transgenic mice. Rev Neurosci 11:59-74.

Wilson RA, Keil KC, eds (1999) The MIT encyclopedia of the cognitive sciences. Cambridge, MA: MIT.

Winder DG, Martin KC, Muzzio IA, Rohrer D, Chruscinski A, Kobilka B, Kandel ER (1999) ERK plays a regulatory role in induction of LTP by theta frequency stimulation and its modulation by $\beta$-adrenergic receptors. Neuron 24:715-726.

Wolfer DP, Muller U, Stagliar M, Lipp H-P (1997) Assessing the effects of the $129 / \mathrm{Sv}$ genetic background on swimming navigation learning in transgenic mutants: a study using mice with a modified $\beta$-amyloid precursor protein gene. Brain Res 771:1-13.

Yan J, Oliveira G, Coutinho A, Yang C, Feng J, Katz C, Sram J, Bockholt A, Jones IR, Craddock N, Cook EH, Vicente A, Sommer SS (2004) Analysis of the neuroligin 3 and 4 genes in autism and other neuropsychiatric patients. Mol Psychiatry 10:329-332.

Yao WD, Gainetdinov RR, Arbuckle MI, Sotnikova TD, Cyr M, Beaulieu JM, Torres GE, Grant SG, Caron MG (2004) Identification of PSD-95 as a regulator of dopamine-mediated synaptic and behavioral plasticity. Neuron 41:625-638. 